\title{
Polysèmes
}

Revue d'études intertextuelles et intermédiales

\section{Orientalising London and the Victorian Era: Questioning Neo-Victorian Politics and Ideologies}

L'orientalisation de Londres et de l'ère victorienne : postures politiques et idéologiques dans le genre néo-victorien

Jaine Chemmachery

\section{OpenEdition}

\section{Journals}

Electronic version

URL: http://journals.openedition.org/polysemes/7382

DOI: $10.4000 /$ polysemes. 7382

ISSN: 2496-4212

Publisher

SAIT

Electronic reference

Jaine Chemmachery, « Orientalising London and the Victorian Era: Questioning Neo-Victorian Politics and Ideologies », Polysèmes [Online], 23 | 2020, Online since 30 June 2020, connection on 02 July 2020. URL : http://journals.openedition.org/polysemes/7382 ; DOI : https://doi.org/10.4000/ polysemes.7382

This text was automatically generated on 2 July 2020.

Polysèmes 


\title{
Orientalising London and the Victorian Era: Questioning Neo- Victorian Politics and Ideologies
}

\author{
L'orientalisation de Londres et de l'ère victorienne: postures politiques et \\ idéologiques dans le genre néo-victorien
}

Jaine Chemmachery

1 In A Study in Scarlet (1887), Arthur Conan Doyle presents Watson and London simultaneously: "I had neither kith nor kin in England, and was therefore as free as air -or as free as an income of eleven shillings and sixpence a day will permit a man to be. Under such circumstances I naturally gravitated to London, that great cesspool into which all the loungers and idlers of the Empire are irresistibly drained" (Doyle 1887, 4). London operates as a magnet for a certain type of outcasts, namely the British who were in the colonies. This passage suggests a strong correlation between London, the centre of Victorian England, and the British Empire.

2 Since the beginning of the twenty-first century, Victorian London has been circulating around the world through Neo-Victorian productions. ${ }^{1}$ Elizabeth Ho, in Neo-Victorianism and the Memory of Empire, echoes the interaction between Victorianism and Empire when she writes: "the return to the Victorian in the present offers a highly visible, highly aestheticized code for confronting empire again and anew; it is a site within which the memory of empire and its surrounding discourses and strategies of representation can be replayed and played out" (Ho 5). According to her, Neo-Victorian productions emerged as a critical response to decolonisation and imperial collapse: fictionalising the past and constructing popular memory, that of London for that matter, could reflect political and psychological engagements with our contemporary post-imperial circumstances. I thus wish to analyse what the visual and literary images of Neo-Victorian London "tell" us about the present.

3 Holmes, the most famous detective of the nineteenth century, is transposed into our contemporary world in the BBC show Sherlock created in 2010 by Mark Gatiss and 
Stephen Moffat. If "the Victorian" has become "a powerful shorthand for empire in the contemporary global imagination" (Ho 5), how are we to interpret the apparent erasure, in Sherlock, of Empire while it was present in Doyle's text? ${ }^{2}$ According to the directors, the motivation behind their modern re-visitation of the Sherlock stories was to "blow [...] away the fog" (Gatiss, qtd in Nicol 125), along with the hansom cabs or costumes, as all are topoi of more traditional adaptations of Doyle's text. While obvious references to the original text may be found in the BBC series, like the deerstalker or the graffiti artist-a modern epitome of the "Baker Street Irregulars"-direct references to London as a once colonial metropolis are hardly visible. My intuition is that this apparent erasure does not just have to do with the plot's transposition in the twenty-first century, especially as neo-imperialism is a feature of our contemporary, globalised world. And traces of imperialist discourse, drawing on Orientalism, can still be found in Sherlock.

What are the effects produced by Neo-Victorian depictions of London? Is the representation of London in Neo-Victorian TV shows part of a "Neo-Victorientalist" strategy which would consist in presenting the city as an "other" to be both feared and domesticated, echoing Edward Said's theorisation of Orientalism in his 1978 seminal study? Some Neo-Victorian works, especially Sherlock (2010-) and Show Time/Sky Atlantic's Penny Dreadful (2014-2016), create an Orientalised image of London whose respective ideological underpinnings need analysing.

\section{Sherlock's orientalised London: atemporality, eternity, monumentality}

5 The incipit of The Crimson Petal and The White by Michel Faber invites twenty-firstcentury readers to discover a city which is not yet named, yet recognisable:

Watch your steps. Keep your wits about you; you will need them. This city I am bringing you to is vast and intricate, and you have not been here before. You may imagine, from other stories you've read, that you know it well, but those stories flattered you, welcoming you as a friend, treating you as if you belonged. The truth is that you are an alien from another time and place altogether. (Faber 3).

The incipit points to the familiarity of the city to the contemporary reader while hinting at the many forms of disconnection between nineteenth-century London and the twenty-first-century (global) readers of the novel.

The founding idea of the Sherlock series adopts the opposite strategy, as it consists in transposing Doyle's text into our contemporary world. This certainly creates an impression of familiarity as the hero evolves in a world which is easily recognisable to a contemporary global audience familiar with Anglo-American televisual products. Text messages and laptops have replaced telegrams and notebooks, London cabs, Doyle's coaches, but what about London itself?

7 In line with Said's concept of "Orientalism", I would argue that making London eternal, atemporal and monumental in Sherlock is part of an orientalising process. Camille Fort showed that the image of the cesspool in Doyle's text suggested immobility while referring at the same time to an idea of mobile perpetuum as London draws to itself outcasts who spent time in the colonies (Fort 159). This contradiction is actually powerfully rendered in the "interlude shots" separating two scenes in the series, notably in season 1 [fig. 1]. 


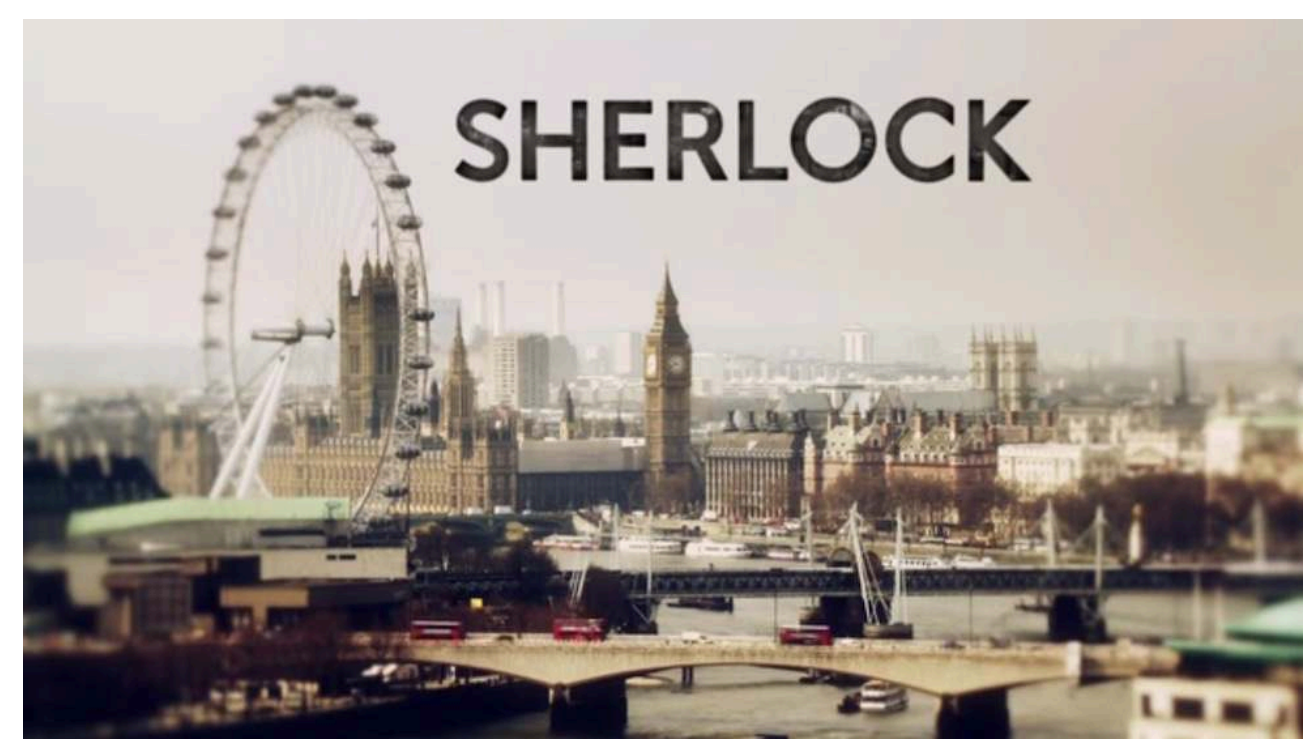

Fig. 1. Screenshot of a transitional shot in season 1 of Sherlock (2010-)

These transitional, speeded-up shots literally echo the phrase "tableau vivant" (Said 158) that Said used to refer to the Orientalised Orient of the nineteenth century, i.e. the Orient as it was imagined by the West. London in these shots appears animated, simultaneously in motion and atemporal, in a state of "permanent transience" (Kohlke \& Gutleben 6). Said also discusses how Orientalist works' internal structure was "in some measure synonymous with a comprehensive interpretation (or an attempt at it) of the Orient" (Said 158). The panoramic shots of Sherlock's London provide the viewers with a comprehensive idea of London, along with a "Romantic restructuring of [it], a re-vision of it, which restores it redemptively to the present" (Said 158). While Said's words obviously apply to the Orientalists' revision of the Orient, they certainly could describe the process that London undergoes in Sherlock. There is no longer fog in the series but the dim lights, among others, contribute to creating a romanticised image of the city.

9 In the second half of the nineteenth century, London and the world were subject to many changes in the wake of the industrial revolution, technological progress and imperial expansion. Ian Baucom evoked London's "cultural aesthetics of movement and speed" (Baucom 59) and argued that the city was the centre of a great national and imperial economy of circulation involving flows of the nation's and the empire's commodities, texts, bodies, etc. London in Sherlock is represented as a global city characterised by such flows, particularly in the interlude shots which turn the city into the direct heir of Empire and nineteenth-century capitalism [fig. 1]. Yet these shots, which sometimes last no more than three seconds, simultaneously create the image of an Orientalised London, turned into a mythic city, de-historicised and decontextualised, just as objects of Orientalist fantasies used to be. London appears as a visual paradox, both frozen in a sort of "postcard aesthetics" and in constant motion. While Said defines Orientalism as "the corporate institution for dealing with the Orient -dealing with it by making statements about it, authorizing views of it, describing it by teaching it, settling it, ruling over it" (Said 3), the imposition of this image of London in Sherlock does not differ much from the authoritative tone that was typical of Orientalist discourse. 

entirely knowable and visible" (Bhabha 101). Sherlock's London is this place that we, contemporary consumers of Neo-Victorian productions, already know thanks to the enduring representation of the same monuments in Anglo-American visual works using London as their background; the very monuments which are highlighted in the opening credits or the transitional shots aforementioned-Piccadilly Circus and the main monuments of the West end (Westminster, Big Ben, the London Eye). Such images of monumental London recall Charlotte Brundson's concept of "landmark London" (Brundson 5) which has become a real trademark as the show circulates around the world, being the synecdoche of (portable) Englishness, an already compressed idea of England made of what Kate Mitchell calls "talismanic traces" (Mitchell 44) or fetishes. Interestingly enough, those very monuments are also highlighted in the opening credits of the special episode set in Victorian times ("The Abominable Bride", 2015). This confirms the effect produced by the show of forms of continuity between nineteenth-century and twenty-first century visions of London which do not just have to do with architecture, but may be more ideologically problematic.

11 It is no coincidence that this show should be produced by the $\mathrm{BBC}$, the British public service broadcaster. London in Sherlock has indeed come to symbolise a certain idea of Englishness in a global context. Some of the BBC productions nowadays labelled "Original British Drama" are clearly positioned as pieces of England to be sold abroad and consumed globally. ${ }^{3}$ Said's remark on the figures of speech associated with the Orient is also worth recalling: "they are all declarative and self-evident; the tense they employ is the timeless eternal; they convey an idea of repetition and strength" (Said 72). If the mode of orientalism is that of "reconstruction and repetition" (Said 122), the recurrent transitional shots in the first season participate in theprobably unintentional-orientalising dimension of the show. Their self-evident dimension is perceptible in the fact that these shots of a fleeting nature do not just punctuate the series. They function as subliminal images whose aim seems to be the branding, on the viewer's retina, of an authoritative image of London.

In her essay on Victorian London's spectral return in Neo-Victorian fiction, Arias discusses the transmission of a certain image of London throughout generations in similar terms: "Victorian London, permanently in motion as a living organism, functions as a 'phantom' in Neo-Victorianism in that it reclaims secrets to be unveiled and disclosed, transmitted silently in 'transgenerational haunting"' (Arias 154-155). What Arias says about fiction applies to Sherlock as these transitional shots, indeed silent, appear as parts of a spectral background that haunts both season 1 and the viewers' imagination of London. London here remains tied to its nineteenthcentury image of (imperial) power while having been orientalised into an ahistorical, mythical, but also commodified object. In that respect, Sherlock seems to share ideological proximity with Peter Ackroyd's conservative model of London. Some critics have underlined that Ackroyd's books were pregnant with a present subject to eternal stasis and abided by a neo-conservative attempt to contain change, along with a form of conservative nostalgia. ${ }^{4}$ The mysterious dimension of London, both present in some Neo-Victorian productions and Said's theorisation of Orientalism, yet needs to be addressed.

Polysèmes, 23 | 2020 


\section{Mysterious London: the other facet of Orientalised London in Neo-Victorian works}

13 In line with Said's theory, an orientalised object is something whose otherness is less real than constructed, yet deemed knowable or controllable: "The Orient is at bottom something either to be feared [...] or to be controlled" (Said 301).

\section{Sherlock's (not so) mysterious London(s)}

London is often seen from above by Sherlock in the BBC series, which turns the main protagonist into a modern-day Caspar David Friedrich, if not a voyeur. This echoes Michel De Certeau's study on New York's skycrapers:

When one goes up there, he leaves behind the mass that carries off and mixes up in itself any identity of authors or spectators. An Icarus flying above these waters, he can ignore the devices of Daedalus in mobile and endless labyrinths far below. His elevation transfigures him into a voyeur. It puts him at a distance. It transforms the bewitching world by which one was "possessed" into a text that lies before one's eyes. It allows one to read it, to be a solar Eye, looking down like a God. The exaltation of a scopic and Gnostic drive: the fiction of knowledge is related to this lust to be a viewpoint and nothing more. (De Certeau 92, emphasis added)

Sherlock is turned not just into a viewpoint, but into a knowledgeable voyeur mastering a therefore "master-able" London. Yet Sherlock is the one able to circumscribe London's mysterious otherness. This is made even clearer in Sherlock as London becomes a sign made of names sometimes reflected on cab windows. The city remains unreadable for most people-like Watson who does not have access to the city's heights-in other words, for De Certeau's "walkers". ${ }^{5}$ The map of London in GPS form in the first season is more disorienting than it is a tool of orientation. ${ }^{6}$ Sherlock's modern London temporarily becomes on screen the London Gissing, talking about Dickens' London, described as "a place [...] of labyrinthine obscurity and lurid fascination" (Gissing 53). The series makes London other for Watson or the spectator while making it possible for the latter-through Sherlock-to imagine the knowability of London, again in orientalising it.

While London in Doyle's fiction used to have an uncanny dimension, the stress laid on its verticality and its façades made of "steel and glass" in the TV show suggests a form of transparency which counters, at first sight, any idea of mystery. What has happened to Watson's-and many Victorian writers'-uncanny London and to Doyle's fascination with the exotic which threatened to invade London interiors?" Victorian London used to be, in the eyes of its contemporaries, a feminine monstrous figure-which, as a matter of fact, already partook of a process of orientalising the city (transforming a territory into a feminine figure to be possibly possessed). London still remains in Sherlock, if not monstrous, at least akin to some organism or body. In season 3, after his alleged death, Sherlock goes on Mycroft's balcony to sense "the thrill of [London's] heart beating" [fig. 2]. 


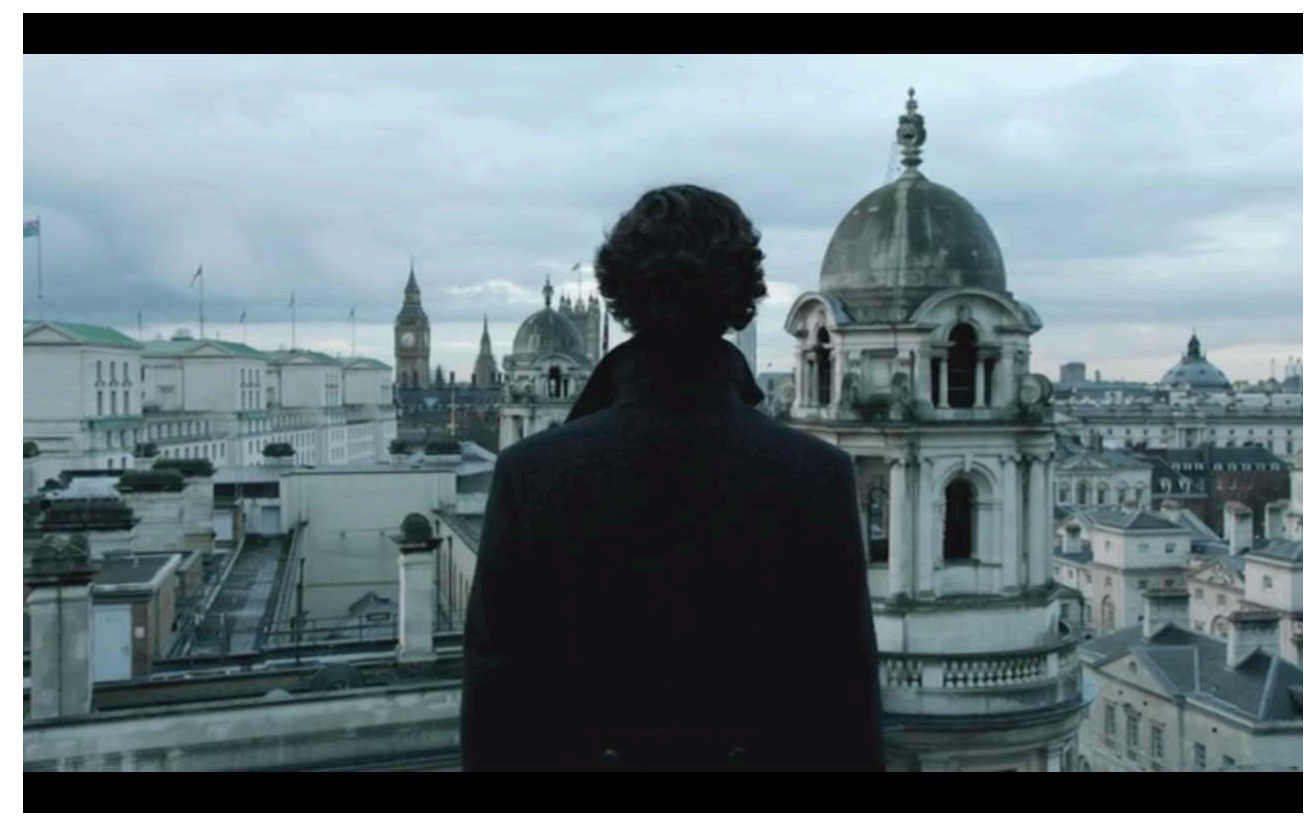

Fig. 2. Sherlock as a viewpoint, screenshot from Sherlock (2010-), season 3, episode 1 ("The Empty Hearse")

But mystery in the series lies elsewhere, in Chinatown for instance. Here is one limited trace of postcolonial presence in a series in which non-Whites are hardly visible. ${ }^{8}$ In Sherlock, there seems to be a strong association between the main protagonists and the nation, based on that between between Holmes and London. As historians such as Nicholas Dirks have shown, England became a nation in the nineteenth century thanks to its empire whose existence precisely helped create others to the English nation and, by default, to England. Sherlock's Chinatown is where the others of the English nation are in the series. Chinatown abounds with stereotypes which assimilate Chinese traders with duplicity as the colonial cliché of the Orientals' indecipherability is transferred onto that of the prices which are written in old Mandarin. The tropes of unassimilable otherness and unfathomable mystery are repackaged into a London Chinatown which is explicitly Orientalist. Chinatown is the literal embodiment of the inaccessible other and directly responds to Said's definition of Orientalism as "a political vision of reality whose structure promoted the difference between the familiar (Europe, the West, 'us') and the strange (the Orient, the East, 'them')" (Said 43). In opposition to a modern global city which seems to be all transparent and technological, like a super-efficient machine whose functioning mode escapes most people, Sherlock problematically identifies indecipherable Chinese subterranean dens with otherness.

Yet, an alternative to explicit Orientalism can be found in Sherlock's re-mythification of London as uncanny through the transposition of the caves or cellars of Doyle's London onto the South Bank (Fort 167-168) [fig. 3]. London's uncanny lies in the world of taggers and street artists, in a form of non-canonical, literally subterranean, culturestill quite white-which viewers, thanks to the detective, may have access to. Although some parts of London are orientalised according to various degrees of mystery in the series, Sherlock remains the figure that turns unknowability into knowledgepotentially to be mastered and controlled. The fact that otherness in Sherlock's London should be circumscribed to well-defined areas in the televisual image of the city and that Sherlock unconditionally masters London's cartography align with the 
conservative form of nostalgia aforementioned. To put it bluntly, otherness is fine as long as it is spatially limited and known by Sherlock, therefore unthreatening to the hero and to the image of England that needs to be conveyed globally.

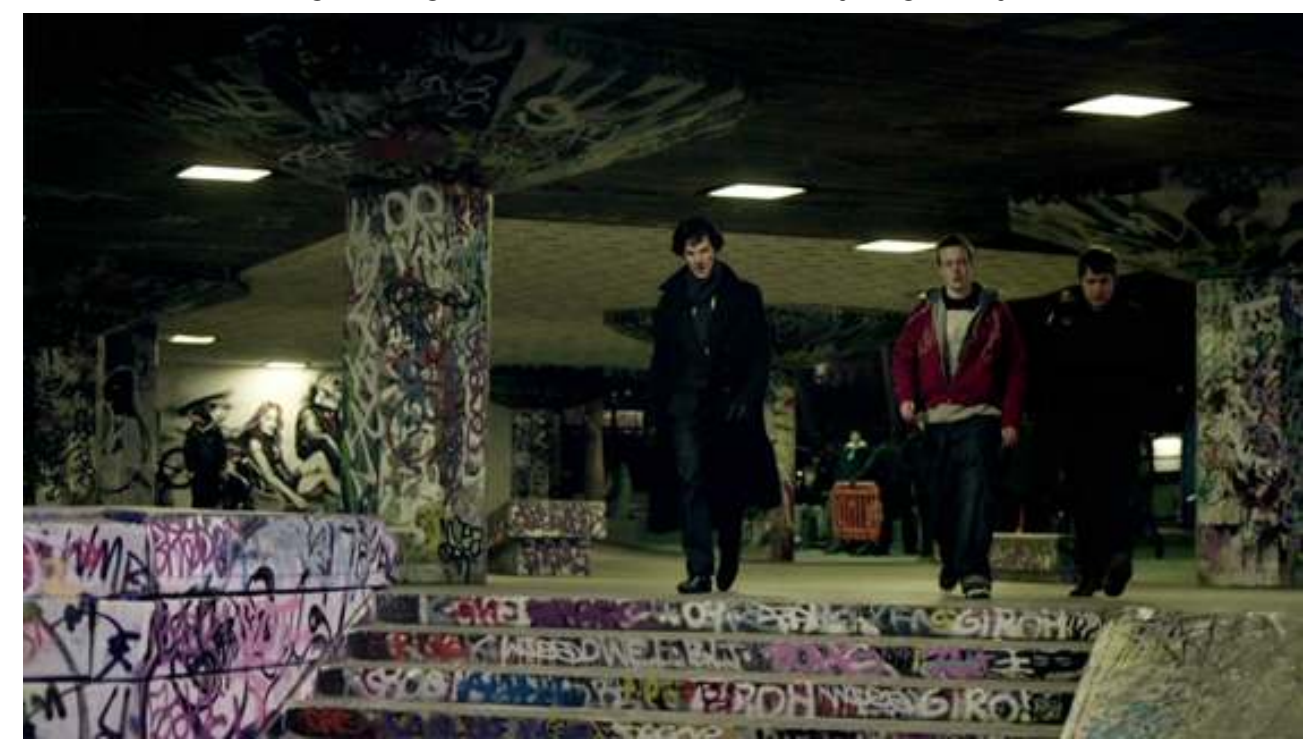

Fig. 3. South Bank: the London other/the other London, screenshot from Sherlock (2010-), season 1, episode 2 ("The Blind Banker")

The idea of London's otherness is linked to the idea, popular in Victorian England, that people may be harbouring secret inner lives, as stories by Stevenson, among others, underlined. This certainly is the central element in several Neo-Victorian works staging London, like The Crimson Petal and the White (2002), Alan Moore's From Hell (1999) or the TV series Penny Dreadful (2014-2016).

\section{The City of the (Penny) Dreadful Night: A Tale of Two Cities}

In Penny Dreadful, London colludes with the demi-monde, which suggests there is a darker alternative to the respectable, Victorian London and its discourse of progress and reason, located in the well-named Underbelly London. In Penny Dreadful a different element of Orientalism is visible, i.e. the sensuous dimension that Orientalists granted to their object of interest. While Sherlock occasionally shows the audience a subterranean London, Penny Dreadful's orientalised London literalises the phrase "Darkest London" used in the 1880s and 1890s. 

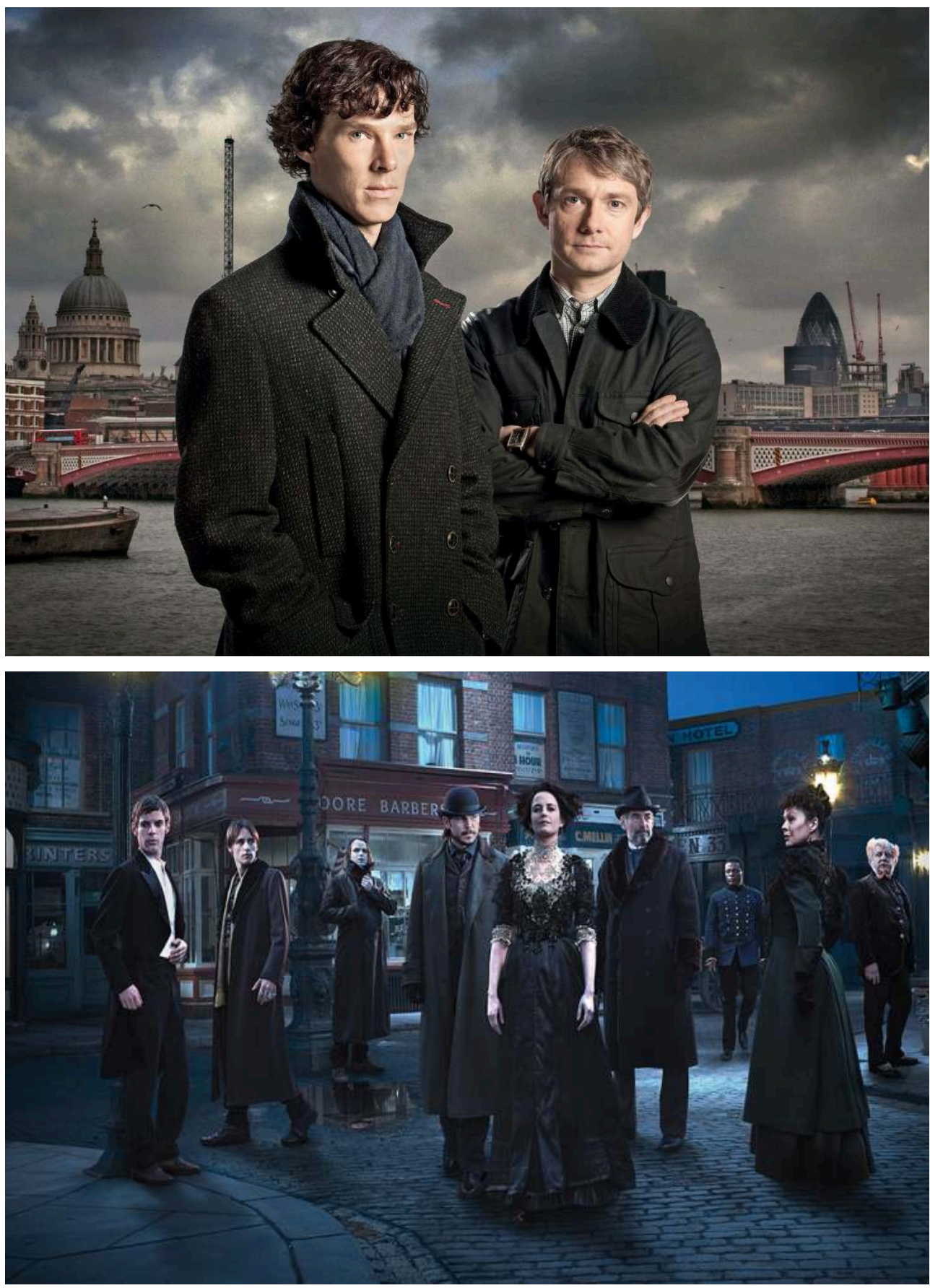

Fig. 4. Monumental London in Sherlock (season 1) vs horizontal, street-centred London in Penny Dreadful (season 1)

In today's global world, where there is no longer an Orient that is a synonym for exoticism, Neo-Victorian London has become the place where the desire of twentyfirst century viewers for exoticism is located. ${ }^{9}$ Chinese opium dens in Penny Dreadful are hiding literal otherworldliness, i.e. experimentations with corpses. As Marie-Luise Kohlke argues, "Gothicised inner-city London became a quasi home-grown British Orient and 'Heart of Darkness' inviting penetration and colonisation, lending itself to all manner of ideological projections and social as well as sexual experimentation" (Kohlke 2018, 184). The insect imagery in Penny Dreadful, forcing the audience to face 
what is deemed to repel "us" in contemporary Western modern imagination also partakes of the creation of this Orientalised London. The fact that Vanessa Ives's token should be a scorpion, not the typical Victorian arachnid, points to Neo-Victorian fascination with the Victorians and exoticism-and the latter's imperial subtext. ${ }^{10}$

The dense accumulation of literary references-Dorian Gray, ${ }^{11}$ Dracula, Frankenstein, Dr Jekyll, etc.-also makes this London composite orientalist. Enumeration happens to be one of the favourite modes of orientalist discourse: "Orientalism is absolutely anatomical and enumerative: to use its vocabulary is to engage in the particularising and dividing of things Oriental into manageable parts" (Said 72). "Orientalist" is therefore a proper adjective to characterise the sub-division of Uncanny London in Penny Dreadful into the supernatural, the erotic/pornographic, the monster hunt, etc. In Imperial Fictions, Rana Kabbani specifies that two main themes arose from the Western construction of the Orient: "The first is the insistent claim that the East was a place of lascivious sensuality, and the second that it was a realm characterised by inherent violence" (Kabbani 24). Penny Dreadful's imagination of London echoes those two trends and offers a different form of Neo-Victorian Orientalism than Sherlock but in both series, categories once projected onto a fantasised Orient, either eternal or mysterious, are projected back onto the English capital city.

The mysterious dimension of Penny Dreadful's London also lies in the dual nature of the city. This duplicity is suggested through the representation of two Londons in the show: on the one hand, the wealthier London of the West End, with the explorer's house, his club, Dorian Gray's mansion with lavish furniture and portraits on the wall; on the other, the poorer London of the East End, symbolised by the Mariner's Inn. Such duplicity is a mirror image of that between respectable London and dirtier London, visible in Faber's The Crimson Petal and the White as well:

I'm introducing you to the very bottom: the lowest of the low. The opulence of Bedford Square and the British Museum may be only a few yards away, but New Oxford Street runs between there and here like a river too wide to swim, and you are on the wrong side. The Prince of Wales has never, I assure you, shaken the hand of any of the residents of this street, or even nodded in passing at anyone here, nor even, under cover of night, sampled the prostitutes. For although Church Lane has more whores living in it than almost any other street in London, they are not of the calibre suitable for gentlemen. (Faber 4)

Apart from the class opposition between the "gentlemen" and the prostitutes of Church Lane, the motif of duplicity appears in phrases with a binary rhythm such as "Bedford Square and the British Museum", "here and there", or the idea of a "wrong side", suggesting there is a right one. The first sentence, also characterised by a binary rhythm, even shows a mise en abyme of duplicity with the polyptoton "the lowest of the low". All those construct London as a dual city. This representation of London can be seen as orientalist as it partakes of a dominant discourse recalling "imperialist rhetoric which transformed the unexplored territory of the London poor into an alien place, both exciting and dangerous" (Walkowitz 18).

The dual nature of Penny Dreadful's London can also be seen in the very fact that to respond to the popular Victorian Gothic image of the city, the directors had to shoot the show in Dublin and in studios. As Victorian London is conflated with Gothic imagination in popular culture, twenty-first-century London is no longer satisfactory: "the historic Dublin cityscape that is integral to the series functions as an unsettlingly similar Gothic double of the real thing" (Louttit 10). Instead of being concerned with 
faithfulness with nineteenth-century London, the directors have plundered "Horror London" (Hutchings 192) to produce an urban Gothic London. To Brundson, this image of the city is a familiar one, and "requires only a gas street lamp, a cobbled street, a horse-drawn carriage and a wisp of mist to be identified" (Brundson 24). As opposed to Sherlock's imagination of the city, London is hardly monumental in Penny Dreadful, but is rather seen from the street point of view. London's verticality is less highlighted, even though the fact that there is an underground London still suggests the existence of different layers. The signs that we are in London in Penny Dreadful are precisely the features highlighted by Brundson even if the series sometimes plays with the tropes of "Horror London". Finally, "Penny Dreadful [...] does not place its narrative in a Victorian London that is a relatively straightforward historical reconstruction. Instead, it adapts our idea of this nineteenth-century metropolis, remoulding this to suit its own imaginative purposes. Indeed, we might take this further and say, more precisely, that it remaps our image of Victorian London" (Louttit 10-11). London's otherness is thus constructed as inner otherness.

Still, as in Orientalist discourse where otherness is to be tamed and made knowable, Penny Dreadful's London escapes any "radical" otherness, first because its Victorian inhabitants remain to a global audience Western neighbours, in terms of geography and temporality, but also because the exotic dimension of Neo-Victorian London otherness implies that the latter remain prone to consumption and assimilation. ${ }^{12} \mathrm{Neo}-$ Victorianism "seeks to 'Other' the nineteenth century [...] only to raise the possibility that we are not, in fact, much more socially conscious, morally superior, genuinely egalitarian or even sexually liberated than our nineteenth-century forebears" (Kohlke 2017, 174). The Orientalist strategies consisting in producing a mythical or an exotic other in the form of London in the two shows precisely annihilate otherness after constructing it. In the end, we recognise Sherlock's London as it is turned into a mythic object as well as we do Penny Dreadful's London and Victorians despite their initial exotic-darker/perverted/sexualised, etc.-dimension. Lily's and Vanessa's incarnations of femininity, initially likely to be seen as other, are pretty much tamed at the end of the series, a masculine order is restored, while both London and the Victorians are transformed into palatable commodities. So despite a more visual, possibly feminine, exoticism, Penny Dreadful finally offers a new form of patriarchal conservatism.

Conversely, a different kind of otherness appears in Moore's and Campbell's graphic novel From Hell where images of monumental London and of a more pagan, violent London are superimposed. Moore's approach is closer to drawing an image of uncanny London while escaping Orientalist strategies. The city has become a palimpsest highlighting this time different layers of history. Contrary to the monumental map of Sherlock, From Hell provides a "deep map", as Ho calls it, "that reveals a more polyglot, pagan, unstable notion of Englishness" (Ho 46) [fig. 5]. Readers are reminded, for instance, that Earl's Court was once “called Billingswell, after Belino's Well, sacred unto the solar God-king Belinos, Son of King Lud" (Moore and Campbell 7). 

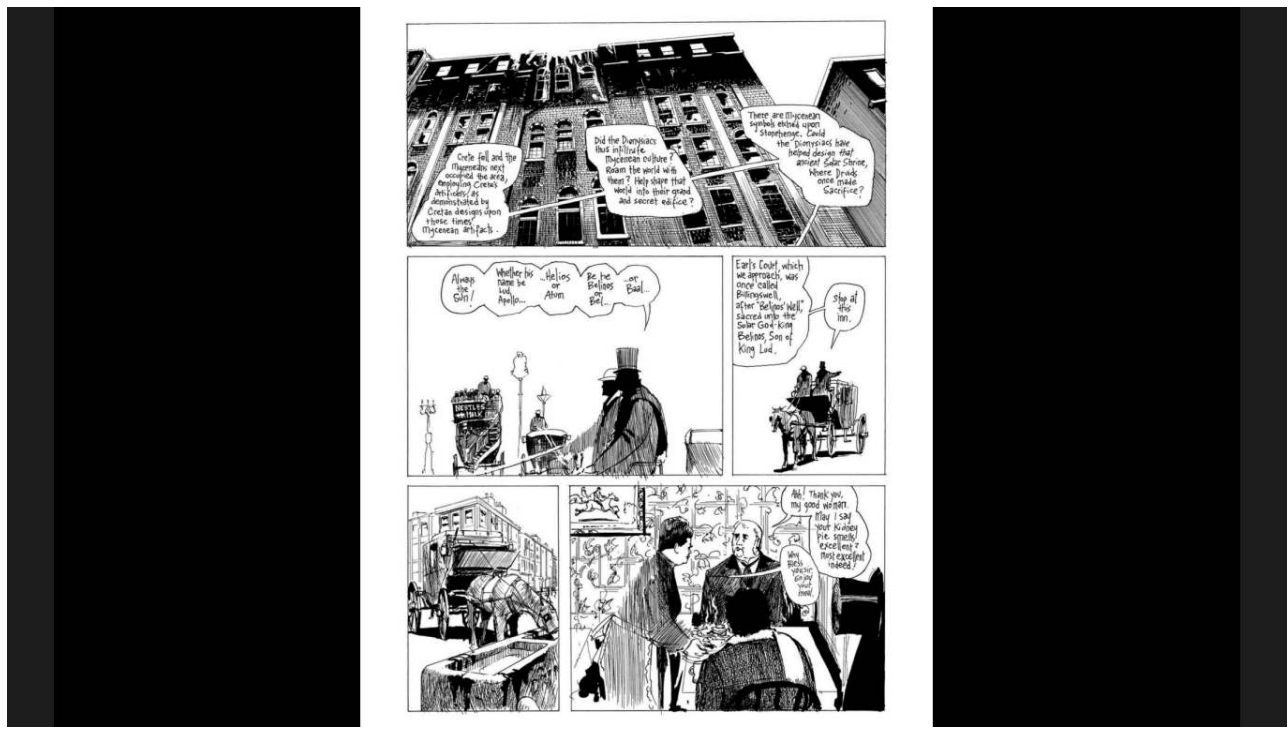

Fig. 5. Gull's "deep map" of London, Alan Moore and Eddie Campbell, From Hell (1999)

\section{(C) Alan Moore \& Eddie Campbell}

The sites mentioned in From Hell are "sites that the official 'monumentality' of London would rather not contain: they stress the excess, the residual and the local that can disrupt or at least provoke a re-evaluation of national belonging or 'consensus' (Lefebvre 2001, 220, qtd in Ho 47). For instance, William Gull's mention of the obelisk in London, "Cleopatra's Needle" [fig. 6], is expanded with information about its pagan origins, as it was "carved fifteen hundred years before Christ's birth", later removed to Alexandria before England, in the nineteenth century, "claimed it and endeavoured to transport it home" (Moore and Campbell 20, emphasis added).
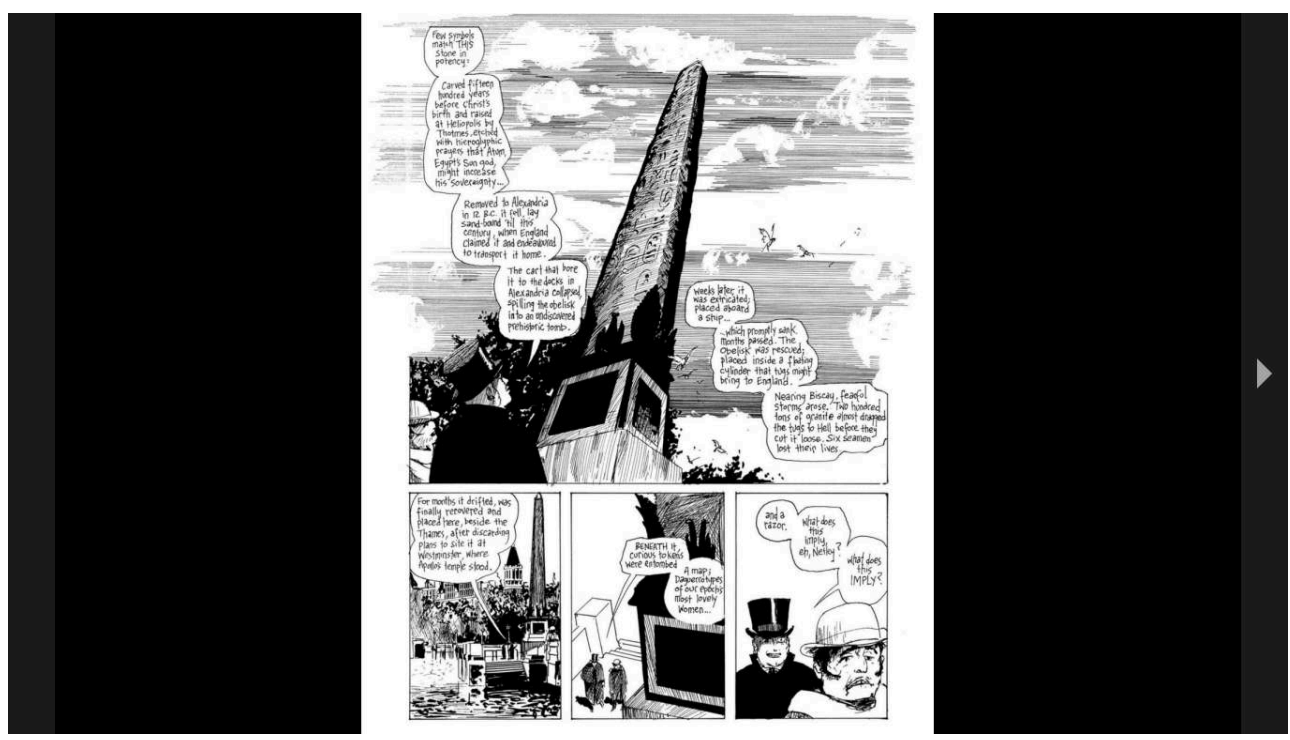

Fig. 6. “Cleopatra's Needle”, Alan Moore and Eddy Campbell, From Hell (1999)

\section{(c) Alan Moore \& Eddie Campbell}

As the protagonist mentions famous London features such as the Thames or Westminster, the capitalisation of the word "BENEATH" does not just refer to the 
tokens that could be found at the bottom of the obelisk. It also points to the less familiar history of violence and death that surrounded the transportation of the stone from Egypt to England, a journey marked by an event close to shipwreck and the death of six seamen. As the modern city of London has been remapped and reconstructed by the officials of history to contain secularised tourist landmarks, "Moore's "deep map" of London offers an alternative to the supposedly stable version of Englishness that such monuments offer" (Ho 47). From Hell, in other words, literalises the subalternist approach of writing a "history from below" and challenges hegemonic narratives of the English nation and its capital city.

Such various representations of London, either as monumental, duplicitous, "exotically mysterious and violent" or uncanny, tell us about contemporary society and ethos. They also raise questions about current anxieties concerning issues of globalisation, migration or urban poverty.

\section{Representing London in Neo-Victorian productions: between (faux-) postmodernism, virtual slumming and critical engagement with the Victorians and Empire}

\section{London as/is a stage}

31 In both Sherlock and Penny Dreadful, and in many Neo-Victorian works, a vindicated, albeit soft, postmodern approach curbs the-potentially radical-political effect of presenting otherness. ${ }^{13}$ In Penny Dreadful for instance, Gothic London is depicted as a stage. In season 3 of Sherlock, the use of Leinster Gardens and its house-fronts, dating back to 1868, when the District Line was constructed, also highlights the theatrical dimension of the show's reconstruction of London (Fort 169).

In Penny Dreadful, theatricality is even more visible in the central figure of the theatre, aptly named "Grand Guignol Theatre". Along with the series is available a "Map of London 1891", based on London's historical map and the show's re-imagination of the city:

The precise detail and recognizable features of the historical street-plan have been obscured by the models of locations such as the Murray Mansion and Grand Guignol placed on the map with what seems like some force. This map, as a result, visually reinforces the fact that this is undeniably Penny Dreadful's London, a place that is at once familiar and strange. It is a composite cityscape that also reflects the processes and preoccupations of the adaptation as a whole, particularly its forms of characterization. (Louttit 2016, 11)

The idea of a place, both recognisable and alien, not only echoes Said's well-known theory of Orientalism, but also his notion of the Orient as a stage:

The Orient is the stage on which the whole East is confined. On this stage will appear figures whose role it is to represent the larger whole from which they emanate. The Orient then seems to be, not an unlimited extension beyond the familiar European world, but rather a closed field, a theatrical stage affixed to Europe. (Said 63)

Neo-Victorian London, just like the Oriental stage in the nineteenth century, aims at defining the contemporary West and it also points to Neo-Victorianism's theatricality itself, which may be linked to the depoliticising effect aforementioned. I am using the 
term "faux-postmodernism", in reference to McRobbie's concept of "faux-feminism" (McRobbie 1) whereby she hints at the self-conscious use of feminist theory in TV shows and series but only as a marketable commodity which deprives the theory of its political radicality. In the shows under study, Orientalist Londons are not depicted as real others since they are finally made knowledgeable and are spatially circumscribed, so the threat they may represent is neutered and the potentially subversive power of the uncanny and the Gothic, similarly annihilated. ${ }^{14}$ Meanwhile, the Victorian others' others, the outsiders of Victorian society, are subject to old stereotypical representations or simply left off screen. Orientalised versions of London may yet provide a foil to current anxieties and issues. Victorians in Neo-Victorian productions are indeed reference points to the way we, readers/viewers of the twentyfirst century, construct our identity.

\section{Neo-Victorian politics and ethics on screen: contradictory directions}

The visual excess and violence present in Penny Dreadful and From Hell could act as cathartic support for our own fears since unpleasantness can be experienced from the comfort of our homes, and Neo-Victorianism's "unhomeliness" only chosen "via remote control" (Kohlke 2018, 196) or time spent reading. Faber's final narratorial address to the reader may aim at countering this: "You fancy that this book will amuse you, thrill you, [...] and that, having consumed it like a sweetmeat, you will be left at liberty to carry on exactly as before! [...] But this book is different, dear Reader. This book is a KNIFE. Keep your wits about you; you will need them! (Faber 816). But even if they are reminded of their complicity in turning cultural products into commodities, readers are always free to close the book and put their minds off Neo-Victorian London and its most displeasing aspects.

Imaginary recreations of London can result from a desire to provide alternative discourses on London, add layers to the many pre-existing layers of historical, literary, cultural, geographical constructions of the city. Neo-Victorian works such as Penny Dreadful or The Crimson Petal and The White also shed light onto the marginal characters of nineteenth-century literature, seem to promote the empowerment of lower-class female characters, and to embrace liberal politics. Postcolonial concepts such as Guha's concept of the "subaltern", in that respect, find an echo in what seem to be ethical Neo-Victorian preoccupations.

Yet, many Neo-Victorian productions are characterised by a paradox, a combination of contradictory intentions. Kohlke argues that this "self-contradictory agenda [is] closely linked to Neo-Victorianism's typical engagement with trauma and its evident penchant for sensationalism and salacious exposés of Victorian sexual scandal (Kohlke 2018, 187). For instance, Penny Dreadful, she writes, veers between "sensationalist trauma tourism and ethical witness-bearing" (Kohlke 2018, 181). The poor, prostitutes, and labourers of Neo-Victorian televisual productions have mostly become commodities for us to consume and absorb. None of their "othered" nature as marginal characters remains in the process which prevents any possible form of empathy with what they may stand for.

Ana Cristina Mendes draws parallels between nineteenth-century slums, slums in postcolonies and the twenty-first century Neo-Victorian imagination of slums and 
questions our ideological and political stance when consuming Neo-Victorian entertainment products:

Suggestively, twenty-first-century Calcutta slums were used as visual inspiration for the TV series' [The Crimson Petal and the White's BBC mini-series, 2011] journeys to spaces of otherness and darkness. Legacies of colonialism have been shaping patterns of European leisure mobilities for centuries; interrelatedly, slumming is a form of leisure mobility that has become ever more popular in the twenty-first century amongst European (and Western) post-tourists visiting locations off the beaten track in the Global South. Using the postcolony as a muse for neo-Victorian slumming on screen, where the slum in the postcolony is seen as a twenty-firstcentury re-enactment of the nineteenth-century Western slum, is hence ripe for scrutiny. (Mendes 5)

In Penny Dreadful, the moment when the main characters are shown helping the poor in the cellars of London is revealing; their escapist enterprise is a mise en abyme of the viewers' potential sense of comfort when they experience horror on screen in NeoVictorian works. ${ }^{15}$ What happens to our ethical intentions towards minorities or marginalised people, who are represented in Neo-Victorian works, when they seem to be undermined by a consumerist crave for Victorian England? In Mendes's words:

Either in neo-Victorian virtual slumming or in actual slum tours in India or Brazil, the unattractiveness of poverty is the attraction, the experience searched for. The experience of poverty at a distance is the commodity sold, consumed by the spectator in the same way-in the sense that the TV series acquires the similitude of a touristic product-as when the tourist books a slum tour in underdeveloped nations. (Mendes 6)

It is thus necessary to reflect on the heterogeneous nature of the "Neo-Victorian political agenda" as it seems to be filled with contradictory trends, with ethical intentions coexisting with reliance on liberal readers and viewers' TV slacktivism and their ambiguous desire to be fed with images of poverty and violence. ${ }^{16}$

Such Neo-Victorian figurations of the Victorians and London may still upset viewers and readers as they do echo realities of today's global metropolises "plagued by the consequences of phenomena (neo-imperialism, neo-capitalism) originating in the age of Victoria" (Costantini 178) such as crime or pollution. Kohlke speaks eloquently of a "process of Gothic seepage, whereby the malevolent urban past seems to extend into the present or, conversely, the present uncannily echoes the past, undermines any defining difference between historically distinct periods and their respective urban realities" (Kohlke 2017, 182). As Kohlke reminds us, in Penny Dreadful (season 2, episode 9), the waxwork proprietor mocks John Clare, telling him: "What care they for the suffering of [...] brutes? They will look, and they will point, [...] and they will pay" (Kohlke 2018, 188). Viewers of Neo-Victorian works become, to some extent, complicit with violence as they are the ones consuming such spectacles and forcing the TV industry to churn out even more shows like this. The character's words sound as a metatextual indictment of how spectators of Neo-Victorian works fully participate in their capitalist cycle of production as well as they, maybe indirectly and unconsciously, endorse the problematic, ambivalent ideology and politics of Neo-Victorian TV productions.

London is often orientalised in Neo-Victorian productions, either turned as in Sherlock into an atemporal myth or an exotic alternative to a more respectable city in Penny Dreadful. Such a process reveals problematic ethical positioning. Traces of Orientalism and imperialism can be found not just in the way the Victorians have 
become the new Orientals in Neo-Victorian productions. According to Dany Van Dam, Neo-Victorian "reconstructed 'Victorian' views of Oriental others always imply twentyfirst century perspectives on those others" $(2017,178)$. The aloof superiority with which we, readers and spectators of the twenty-first century, may consider the Victorian period as it is staged in Neo-Victorian productions, along with the Orientalist commodification of the Victorians, needs questioning, as well as the exhibition of violence and spectacularisation of poverty that are hallmarks of Neo-Victorianism.

Readers and viewers of Neo-Victorian works are still reminded of "continuities" between Victorian urban experience and contemporary one. If such productions may raise our (twenty-first-century viewers') awareness in regard to our ethical responsibility, they also question our ideological and political positioning as they combine seemingly incompatible aspects. The viewers' feeling of upset may be debunked by the overtly theatrical dimension of Neo-Victorian works, which at once constructs and deconstructs otherness, and by the fact that such works are still largely associated with the entertainment industry where critical issues are often subsumed under more commercial preoccupations. Yet in the current context of Brexit and the global rise of populist movements, the choices made by Neo-Victorian authors to represent London and the Victorians do have an impact. Neo-Victorian works reveal anxieties about issues of identity, care and commonality in our globalised world that need to be addressed as well as they possibly invite us to "consume the Victorians" more ethically.

\section{BIBLIOGRAPHY}

Arias, Rosario. "Haunted Places, Haunted Spaces: The Spectral Return of Victorian London in Neo-Victorian Fiction". Haunting and Spectrality in Neo-Victorian Fiction: Possessing the Past. Rosario Arias and Patricia Pulham (eds.). New York: Palgrave Macmillan, 2009, 133-156.

Baucom, Ian. Out of Place: Englishness, Empire, and the Locations of Identity. Princeton: Princeton UP, 1999.

Bhabha, Homi. The Location of Culture (1994). New York/London: Routledge, 2010.

Botting, Fred. Gothic: The New Critical Idiom (2003). London: Routledge, 2014.

Bran, Nicol. "Sherlock Holmes Version 2.0: Adapting Doyle in the Twenty-First Century". Sherlock Holmes and Conan Doyle. Sabine Vanacker and Catherine C. Wynne (eds.). London: Palgrave Macmillan, 2013, 124-139.

Brundson, Charlotte. London in Cinema: The Cinematic City Since 1945. London: BFI, 2007.

De Certeau, Michel. The Practice of Everyday Life (1988). Translated by Steven Rendall. London/ New York: U of California P, 2011.

Doyle, Sir Arthur Conan. A Study in Scarlet (1887). London: Penguin Classics, 2014.

Faber, Michel. The Crimson Petal and the White. Edinburgh: Canongate, 2002. 
Fort, Camille. "Sleuth in the City: La Londres de Sherlock Holmes et la Londres de Sherlock". Sherlock Holmes, un nouveau limier pour le XXI ${ }^{e}$ siècle : Du Strand Magazine au Sherlock de la BBC. Jean-Pierre Naugrette (ed.). Rennes : PU de Rennes, 2016, 159-172.

Gatiss Mark, and Stephen Moffat, Sherlock, seasons 1 to 3, BBC, 2010-2014.

Gissing, George. Charles Dickens: A Critical Study (1898). London: Blackie, 1929.

Gutleben, Christian. « Travail de mémoire ou travail de marchandisation ? Esthétique et idéologie de la fiction néo-victorienne ». Aesthetics and Ideology in Contemporary Literature and Drama.

Madelena Gonzalez and René Agostini (eds.). Newcastle upon Tyne: Cambridge Scholars, 2015, 117-130.

Hardy, Thomas. The Life and Work of Thomas Hardy. Michael Millgate (ed.). London/Basingstoke: Macmillan, 1984.

Heilmann, Ann, and Mark Llewellyn. Neo-Victorianism:The Victorians in the Twenty-First Century, 1999-2009. Basingstoke: Palgrave Macmillan, 2010.

Ho, Elizabeth. Neo-Victorianism and the Memory of Empire (2012). London/New York: Bloomsbury Academic, 2013.

Hughes, Albert and Allen. From Hell, film with Johnny Depp, Heather Graham, Ian Holm, Robbie Coltrane, 2011.

Hutchings, Peter. "Horror London”. Journal of British Cinema and Television 6.2 (2009): 190-206.

James, Henry. "London". Essays in London and Elsewhere. New York: Harper and Brothers, 1893.

Kabbani, Rana. Imperial Fictions: Europe's Myths of the Orient. London: Saqi, 2008.

Kohlke, Marie-Luise. "Sexsation and the Neo-Victorian Novel: Orientalising the Nineteenth Century in Contemporary Fiction". Negotiating Sexual Idioms: Image, Text, Performance. Marie-Luise Kohlke and Luisa Orza (eds.). Amsterdam/New York: Rodopi, 2008, 53-77.

Kohlke, Marie-Luise and Christian Gutleben, "Troping the Neo-Victorian City: Strategies of Reconsidering the Metropolis" in Marie Luise Kohlke and Christian Gutleben (eds.), Neo-Victorian Cities: Reassessing Urban Politics and Poetics. Leiden/Boston: Brill/Rodopi, 2014. 1-40.

Kohlke, Marie-Luise. “Adaptive/Appropriative Reuse in Neo-Victorian Fiction: Having One's Cake and Eating It Too". Interventions: Rethinking the Nineteenth-Century. Andrew Smith and Anna Barton (eds.). Manchester: Manchester UP, 2017, 169-187

Kohlke, Marie-Luise. “Neo-Victorian Slumming in London's Gothicity: The Victorian Metropolis' Televisual Transformation into 'The City of Dreadful Night”. Transforming Cities: Discourses of Urban Change. Monika Pietzrak-Franger, Nora Pleßke, and Eckart Voigts (eds.). Heidelberg: Universitätsverlag Winter, 2018, 181-210.

Logan, John. Penny Dreadful. Showtime/ Sky, 2014-2016.

Longley, Kateryna Olijnyk. "Fabricating Otherness: Demidenko and Exoticism". "New" Exoticisms: Changing Patterns in the Construction of Otherness. Isabel Santaolalla (ed.). Amsterdam/Atlanta: Rodopi, 2000, 21-39.

Louttit, Chris. "Victorian London Redux: Adapting the Gothic Metropolis". Critical Survey and Berghahn Books 28.1 (2016): 2-14.

McRobbie, Angela. The Aftermath of Feminism: Gender, Culture and Social Change. Los Angeles: Sage, 2009. 
Mendes, Ana Cristina. "Neo-Victorian Slumming on Screen". Continuum: Journal of Media and Cultural Studies 31.6 (2017), https://doi.org/10.1080/10304312.2017.1370537 (last accessed 17 December 2019).

Mitchell, Kate. "Making and Unmaking 'Marvellous Melbourne': The Colonial City as Palimpsest in Neo-Victorian Fiction and Non-Fiction". Neo-Victorian Cities: Reassessing Urban Politics and Poetics. Marie Luise Kohlke and Christian Gutleben (eds.). Leiden/ Boston: Brill/Rodopi, 2014, 43-70.

Moore, Alan, Eddie Campbell, Pete Mullins. From Hell: Being a Melodrama in Sixteen Parts. E. Campbell. Marietta (GA): Top Shelf Production, 1989-1999.

Reitz, Caroline. "The Empires of A Study in Scarlet and The Sign of Four." The Cambridge Companion to Sherlock Holmes. Janice M. Allan and Christopher Pittard (eds.). Cambridge/New York: Cambridge UP, 2019, 127-139.

Said, Edward. Orientalism (1978). New York: Vintage Books, 2003.

Santaolalla, Isabel. "Introduction: What is 'New' in 'New' Exoticisms?". "New" Exoticisms: Changing Patterns in the Construction of Otherness. Isabel Santaolalla (ed.). Amsterdam/Atlanta: Rodopi, 2000, 9-17.

Seth, Koven. Slumming: Sexual and Social Politics in Victorian London. Princeton/Oxford: Princeton UP, 2004.

Van Dam, Dany. "A Conscious Failure to Pass: Dressing across Sexual and Racial Borders in NeoVictorian Fiction”. Neo-Victorian Studies 9.2 (2017): 154-182.

Walkowitz, Judith R. City of Dreadful Delight: Narratives of Sexual Danger in Late-Victorian England. Chicago: The U of Chicago P, 2013.

\section{NOTES}

1. The term "Neo-Victorian" is used in the vein of Ann Heilmann's and Mark Llewellyn's definition according to which what is called "neo-Victorian" is not just historical fiction set in the nineteenth century; it implies being 'self-consciously engaged with the act of (re)interpretation, (re)discovery and (re)vision concerning the Victorians' (Heilmann and Llewellyn 4, original italics).

2. "The worlds of A Study in Scarlet and The Sign of Four are messy and global. Brutal western expansion and ruthless consolidation of power in the Mormon community are the focus of the American half of A Study in Scarlet, while a good portion of The Sign of Four is given over to Jonathan Small's retelling of a plot to steal Indian treasure that leaves a long trail of murder. These crimes do not stay contained in America or India but [...] are woven into investigations of crime on English soil" (Reitz 128).

3. From Hell (2011), the film adaptation of Moore's and Campbell's work starring Johnny Depp is a telling example of the packaging of Victorian England, yet with a popular American actor, so that it should be palatable to a young American audience and likely to travel more easily across global borders.

4. In the context of Brexit, it is difficult not to see current discussions about the need for Britain to regain its sovereignity as traces of nostalgia for Britain's imperial "grandeur".

5. "The ordinary practitioners of the city live 'down below', below the thresholds at which visibility begins. They walk-an elementary form of this experience of the city; they are walkers, Wandersmänner, whose bodies follow the thicks and thins of the 'urban text' they write without being able to read it. These practitioners make use of spaces that cannot be seen; their knowledge 
of them is as blind as that of lovers in each other's arms. The paths that correspond in these intertwining, unrecognized poems in which each body is an element signed by many others, elude legibility" (De Certeau 93).

6. For an interesting analysis of the GPS imagination of London in the series, see Camille Fort's essay "Sleuth in the City" (Fort 170).

7. Thomas Hardy, for instance, thought of London as "a monster whose body had four million heads and eight million eyes" (Hardy 141). Henry James, in his essay on London, wrote in similar terms: "London is so clumsy and brutal, and has gathered together so many of the darkest sides of life"; "[The city has become] a strangely mingled monster [...] [an] ogress who devours human flesh to keep herself alive to do her tremendous work" (James 27-32).

8. It certainly is at odds with CBS's adaptation of Doyle's stories, Elementary (2012), which features a female Asian-American Watson and a female Moriarty, among others, and thus seems to engage more with twenty-first- century identity politics.

9. "[T] he neo-Victorian novel exoticises and seeks to penetrate the tantalising hidden recesses of the nineteenth century by staging a retrospective imperialism" (Kohlke 2008, 62). About the Orient, Kohlke writes that it "is no longer somewhere else out there [...] our imagined Victorian Others supplant the Orient to become what Said called 'a sort of surrogate and even underground self" (Kohlke 2008, 69).

10. "Exoticism, like orientalism, is a way of seeing which sustains the myth of the cultural centrality, and therefore, the superiority of the viewer" (Longley 23).

11. For an analysis of the re-viewing of Oscar Wilde's The Picture of Dorian Gray, see Camille Martin-Payre's essay in this volume.

12. In her introduction to New Exoticisms, Isabella Santaolalla recalls that exotic products bombarding Western cultural markets all share: "a common symbolic space: one in which an agency appropriates a 'colonised', domesticated version of an Other to meet its own needs" (Santaolalla 10).

13. See Christian Gutleben's notion of "post-modernisme soft (soft po)" (Gutleben 120).

14. Fred Botting recalls that "Gothic figures [are] always responsive to changing times". Their adaptability has them function as "sites of projection and fantasy, metaphors of form and medium, screens of anxiety and desire operating at the limits of norm and meaning". Yet, their omnipresence in contemporary popular culture leads to a loss in "features and effects that once, negatively in fear or horror, charged them with significance" (Botting 199).

15. Ana Cristina Mendes reminds us that the Neo-Victorian commodification of poverty dates back to the Victorian era: "In the Victorian era, the commodification of urban poverty and violence grew out of anxieties about the degeneration of the moral and social health of the nation as mirrored in the capital's urban space. Such cultural anxieties were materialized in both virtual slumming-for example, in social realist novels, etchings, paintings and drawings that took the bourgeois reader into the urban demimonde-and actual slumming-i.e in organized tours of London's East End. The experience of viewing Crimson Petal on the small screen can thus be construed as a form of virtual, armchair tourism experience whereby audiences engage in 'window shopping' (Friedberg 1994) without actually moving from their seats" (Mendes 2).

16. Seth Koven explained that slumming was, and is, never totally altruistic: "Eros and altruism, self-gratification and self-denial, the desire to love the poor and to discipline their disruptive power: these seemingly opposed impulses were tightly and disconcertingly bound to one another" (Koven 284). 


\section{ABSTRACTS}

In this essay, I am looking at how Victorian/Imperial London circulates around the world nowadays through Neo-Victorian productions. In Neo-Victorianism and the Memory of Empire (2012), Elizabeth Ho argues that Neo-Victorian productions emerged as a critical response to the crises of decolonisation and imperial collapse. While Sherlock Holmes, the most famous detective of the nineteenth century, is transposed into our contemporary world in the BBC show, one may wonder to what extent the series, and us viewers, engage with the Victorians. London, as it is imagined in Neo-Victorian productions, will be the main focus of this article. Is the representation of Victorian London in Neo-Victorian TV shows not part of a Neo-Victorientalist strategy which would consist in presenting the city as an "other" to be both feared and domesticated, echoing Edward Said's theorisation of Orientalism? What are the political and ideological implications of such re-visions? Questions bringing together Neo-Victorian works, politics and the global economy of production, circulation and consumption-which we have precisely inherited from the Victorians-will be addressed here.

Cet article étudie la manière dont le Londres victorien circule aujourd'hui dans le monde à travers les objets culturels néo-victoriens. Certaines œuvres littéraires, télévisuelles et filmiques véhiculent une image de l'Angleterre victorienne métonymiquement contenue dans celle de Londres. Cette représentation de Londres oscille entre une vision monumentale de la capitale et une vision de celle-ci comme ville double constituée d'un envers mystérieux, ce qui n'est pas sans rappeler le discours orientaliste tel qu'il a été théorisé par Edward Said en 1978. La construction littéraire et visuelle du Londres néo-victorien participe donc d'une stratégie néo-victorientaliste présentant la ville comme un «autre», à la fois à craindre et à domestiquer. Dans NeoVictorianism and the Memory of Empire (2012), Elizabeth Ho montre que les productions néovictoriennes constituent une réaction à la décolonisation et la chute des empires européens. Alors que Sherlock Holmes, le plus célèbre détective du XIX ${ }^{\mathrm{e}}$ siècle, est catapulté dans notre monde dans la série de la BBC et que Penny Dreadful nous plonge dans un Londres gothique et fantasmé, on s'interrogera sur les modalités d'engagement des spectateurs et spectatrices avec les Victoriens. Comment l'articulation entre le politique, l'économie globale de production et de circulation des objets culturels et les œuvres néo-victoriennes nous permet-elle de penser les enjeux politiques, idéologiques et éthiques de notre engagement contemporain avec les Victoriens?

\section{INDEX}

oeuvrecitee Study in Scarlet (A), Sherlock, Penny Dreadful, From Hell, Crimson Petal and The White (The)

Keywords: neo-Victorian, Empire, London, series, fiction, ideology, politics, ethics, consumption Mots-clés: néo-victorien, Londres, série, fiction, idéologie, politique, éthique, consommation

\section{AUTHORS}

\section{JAINE CHEMMACHERY}

Jaine Chemmachery is an alumna of the École normale supérieure de Lyon and a Senior Lecturer at University Paris-Dauphine-PSL. She is a member of the research centre "Transcrit" (EA 1569), 
based at University Paris 8 Vincennes-Saint-Denis. She wrote a PhD dissertation on R. Kipling and S. Maugham's colonial short stories and the relation between colonialism, modernity and the genre of the short story (2013). Her main research fields are colonial and postcolonial literature, Victorian and Neo-Victorian literatures, modernity and spectrality studies. Her most recent publications include an article entitled "'Bricks Are Undoubtedly an Essential Ingredient of Civilisation': Layers of Reconstruction in J.G. Farrell's The Siege of Krishnapur (1973)" (Commonwealth Essays and Studies 40.2 [2018]) and an article entitled "Cross-dressing and Empowerment in Anglo-Indian Fiction: Embracing Subaltern Invisibility" (E-rea 16.2 [2019], last accessed 26 December 2019, URL : http://journals.openedition.org/erea/7645) 